\title{
Studying phenological stages of cherry (Prunus avium L.) using field observations and satellite-derived vegetation indexes
}

\author{
Estudio de los estados fenológicos en cerezo (Prunus avium L.) utilizando \\ observaciones de campo e índices de vegetación derivados de imágenes satelitales
}

Eduardo von Bennewitz Alvarez, Rodrigo Cazanga-Solar ${ }^{2}$, Marcos Carrasco-Benavides ${ }^{3}$

\begin{abstract}
In the framework of a continuous search for technological innovations that allow fruit growers to practice a more competitive and sustainable fruit production, satellite-derived vegetation indexes could be used as tools to support the decision-making processes of technicians and territory planners. The objectives of the present study were to characterize phenological stages of cherry trees (Prunus avium L.) in the Maule region of Chile using field observations and to evaluate the capacity of multispectral satellite imagery (Landsat ETM+) and the derived vegetative indexes (NDVI, SAVI), as tools for remotely identifying these phenological stages in cherry trees. Phenological transition stages in cherry trees, estimated from Landsat 7 (ETM+) data did not agree with in situ measurements of phenology made at the different sites. Landsat 7 (ETM+) derived vegetation indices (NDVI, SAVI) could discriminate only gross changes associated with an increase and then a decrease of canopy greenness in cherry trees, but could not discriminate between successive phenological states in which the proportion of foliage is only slightly different. The number of days after the first of July (Southern Hemisphere) tended to be a less variable indicator than growing degree-days (GDD) for predicting the occurrence of different phenological stages in cherry trees.
\end{abstract}

Key words: Fruit trees, Landsat 7 (ETM+), NDVI, phenology, SAVI.

\section{RESUMEN}

En el marco de una búsqueda continua de innovaciones tecnológicas que permitan a los fruticultores practicar una producción frutícola más competitiva y sostenible, el uso de índices de vegetación derivados de satélites podría ser utilizado como herramienta para apoyar la toma de decisiones por parte de técnicos y planificadores del territorio. Los objetivos del presente estudio fueron caracterizar las etapas fenológicas de los cerezos (Prunus avium L.) en la región del Maule-Chile utilizando observaciones de campo y evaluar la capacidad de las imágenes satelitales multiespectrales (Landsat ETM +) y los índices vegetativos derivados (NDVI, SAVI), como herramientas para la identificación remota de las distintas etapas fenológicas en cerezo. La estimación de las etapas de transición fenológica en cerezos, estimadas a partir de los datos de Landsat $7($ ETM +), no coinciden con sufiente robustez con las mediciones in situ de fenología medidas en los diferentes sitios. Los índices de vegetación (NDVI, SAVI) derivados de Landsat $7(E T M+)$, permiten discriminar sólo cambios gruesos asociados con un aumento y leugo disminución del verdor en el follaje, pero no permiten discriminar entre estados cercanos de fenología en los que la proporción de follaje es sólo ligeramente diferente. En este estudio, el número de días acumulados a partir del primero de julio (Hemisferio Sur) tiende a ser un indicador menos variable que los Grado-día (GDD) para predecir la ocurrencia de diferentes etapas fenológicas en los cerezos.

Palabras clave: Árboles frutales, Landsat 7 (ETM +), NDVI, fenologia, SAVI.

\section{Introduction}

Knowledge about variations in vegetation phenological cycles and growth provide valuable insight into the climatic and physio-geographic characteristics of an area (Jensen, 2005). Phenological models, by informing farmers of crop growth and development stages during the growing season, can be useful tools for improving the efficacy and timing of crop management (Chmielewski, 2003). In the frame of a continuous search for technological innovations that allow fruit growers to practice a more competitive and sustainable fruit production, remote sensing and the

\footnotetext{
Institute of Plant Production and Protection, Campus Isla Teja, Universidad Austral de Chile, Valdivia-Chile.

2 Laboratorio de Investigación de Ciencias Ambientales (LARES), Universidad de Chile, Chile.

3 Universidad Católica del Maule, Escuela de Agronomía.

* Correspondence: eduardo.vonbennewitz@uach.cl
} 
use of multispectral satellite images could be used as tools to support the decision-making process by technicians and territory planners. Especially in strategic decisions as for example the selection of zones for cultivation, selection of varieties, training systems, density of the plantation, timing of phytosanitary controls, application of fertilizers and thinning, among others, may be supported by information obtained through in situ, plot-level phenological measurements and satellite-derived phenological studies. Cherry trees have unique phenological cycles in each geographic region which may be measured using remotely sensed data at critical dates in the phenological cycle. Satellite images have some advantages over field observations and measurements for obtaining the information needed to support decision making in cherry production. Among the advantages of satellite images over other means, the following may be emphasized (Chuvieco, 2002): Global and exhaustive capacity; capacity of comparison on a global scale; panoramic perspective, capacity to study large land surfaces of cherry trees with a single image; capacity to obtain information in shorter times than field observations and measurements; digital format and IT technologies that facilitate the management of a large volume of information and the speed of processing of this information. There is also a need for datasets and methods that link ground-based observations of phenology to moderate resolution land surface phenology products (Melaas et al., 2013). Field-to-satellite scaling is difficult due to the large spatial step required to bridge point studies and coarse resolution satellites; in broad-scale studies, compositional errors and the loss of high-frequency data are frequent (Rastetter et al., 1992). Vegetation indices such as the normalized difference vegetation index (NDVI) are widely used to monitor seasonal, inter-annual and long-term variation of structural, phenological and biophysical parameters of vegetation cover (Barbosa et al., 2006; Piao et al., 2006). The Soil-adjusted vegetation index (SAVI), developed by Huete (1988), has been reported to work well in semiarid ecosystems because it minimizes soil background effects that are known to affect other indices as the NDVI (Jensen, 2007). To the best of our knowledge no studies have been carried out in Chile using remote sensing and vegetation indices to study the phenological stages of cherry. This study had two main objectives: (1) To characterize phenological stages of cherry trees (Prunus avium L.) using field observations and (2) to evaluate the capacity of multispectral satellite imagery (Landsat ETM+) and the derived vegetative indexes (NDVI, SAVI) as tools for remotely identifying these phenological stages in cherry trees.

\section{Materials and Methods}

The study was carried out during 2010 and 2011 in the Maule Region of Chile. Three cherry orchards were selected for the study $(\mathrm{C} 1$, $\mathrm{C} 2$, and C3). Plant material consisted of 'Bing' sweet cherry trees planted in 2004 on 'Gisela 6' rootstock; spaced $3 \times 4 \mathrm{~m}$ in north to south rows and trained to a Solaxe system (Laurie, 2005). The locations of the cherry orchards used in the study are given in Table 1.

The trees were selected on the basis of uniform vigor and development. Standard orchard management practices (irrigation, fertilization, weed control, pruning) were followed each year. The soils at the sites belong to the Romeral (Andosols) and Macarena soil series (Cambisols) (Casanova et al., 2007). The climate of the region is Mediterranean, with the rainy season occurring primarily during winter months while the summer is quite dry. Mean annual precipitation is $700 \mathrm{~mm}$; mean annual temperature in the region is $15^{\circ} \mathrm{C}$. Detailed phenological observations of flower bud development were carried out weekly over two growing seasons (2010-2011 and 2011-2012) in the three cherry orchards $(\mathrm{C} 1, \mathrm{C} 2$, and $\mathrm{C} 3)$ detailed in Table 1. During this time, phenological stages were characterized sequentially. In situ

Table 1. Location of cherry orchards for the study.

\begin{tabular}{cclll}
\hline Orchard & Cultivar/rootstock & \multicolumn{1}{c}{ Site } & \multicolumn{2}{c}{ Geographic coordinates (WGS 84) } \\
\hline C1 & Bing/Gisela & Romeral & $34^{\circ} 57^{\prime} 24.06^{\prime \prime} \mathrm{S}$ & $71^{\circ} 9^{\prime} 9.75^{\prime \prime} \mathrm{W}$ \\
C2 & Bing/Gisela & Rauco & $34^{\circ} 56^{\prime} 22.28^{\prime \prime} \mathrm{S}$ & $71^{\circ} 15^{\prime} 33.50^{\prime \prime} \mathrm{W}$ \\
C3 & Bing/Gisela & Sgda. Familia & $35^{\circ} 00^{\prime} 31.40^{\prime \prime} \mathrm{S}$ & $71^{\circ} 24^{\prime} 8.60^{\prime \prime} \mathrm{W}$ \\
\hline
\end{tabular}


phenological characteristics were collected in ten randomly selected trees of similar development in each of the three studied sites. The phenology of each tree was recorded in four random shoots per tree, selected in the south, north, west, and east quadrants of the canopy (Zavalloni et al., 2006). The extended BBCH-scale (Meier, 1997) was utilized to encode phenologically similar growth stages of the trees, based on the dominant phenological stage assessed across the entire canopy. Daily minimum and maximum temperatures were used to calculate growing degree-days (GDD) with the averaging method (average daily temperature base temperature).

$\mathrm{GDD}=\frac{(\text { Temp. max }+ \text { Temp. } \min )}{2}-$ Base temp $(1)$

Base temperatures of $6{ }^{\circ} \mathrm{C}$ and $10{ }^{\circ} \mathrm{C}$ were selected. Representative daily weather data to calculate GDD were acquired from automatic iMetos AG/CP/DD 200 weather stations installed at each of the three sites. The end of the leaf bud swelling stage was used for the onset of growth, with GDD accumulated starting on 1 July. This date is an approximation of the earliest beginning of development across the study area.

Eight Landsat 7 (ETM+) satellite images were obtained from the USGS Glovis website (http:// glovis.usgs.gov/) in the period from January, 2010 to December, 2011 (Table 2). Some images were discarded if they presented more than $30 \%$ cloud cover (Carrasco-Benavides et al., 2014). They were also discarded if the pixels that fell inside the area of the study presented gaps due to the failures in the satellite scan line corrector (slc-off). All Landsat images used in this study

Table 2. Satellite images selected for the study.

\begin{tabular}{cccc}
\hline Year & $\begin{array}{c}\text { Date } \\
\text { (mm-day-year) }\end{array}$ & Satellite & $\begin{array}{c}\text { Overpass* } \\
\text { time }\end{array}$ \\
\hline \multirow{2}{*}{2010} & $01-22-2010$ & Landsat 7 (ETM+) & $11: 24: 47$ \\
& $04-12-2010$ & Landsat 7 (ETM+) & $11: 24: 47$ \\
& $11-06-2010$ & Landsat 7 (ETM+) & $11: 24: 49$ \\
\hline \multirow{4}{*}{2011} & $01-09-2011$ & Landsat 7 (ETM+) & $11: 18: 16$ \\
& $03-30-2011$ & Landsat 7 (ETM+) & $11: 23: 38$ \\
& $09-06-2011$ & Landsat 7 (ETM+) & $11: 23: 50$ \\
& $11-25-2011$ & Landsat 7 (ETM+) & $11: 24: 06$ \\
& $12-11-2011$ & Landsat 7 (ETM+) & $11: 24: 26$ \\
\hline
\end{tabular}

were downloaded considering that they presented a default standard terrain correction (Level 1T-precision and terrain correction) which is provided by USGS Clovis. These corrections included several systematic radiometric and geometric corrections based on ground control points and a Digital Elevation Model (DEM) (topographic accuracy standard terrain correction) (Carrasco-Benavides et al., 2014).

The at-satellite (or top of atmosphere - TOA) reflectance was computed according to Allen et al. (2007) and Tasumi et al. (2008) and the at-surface reflectance was calculated by applying the atmospheric correction proposed by Tasumi et al. (2008). Each satellite image was processed with the model maker toolbox of the software ERDAS (ERDAS Inc., USA). The selection of pixels that fell inside each fruit orchard was as suggested by Carrasco-Benavides et al. (2014); by excluding a perimeter of $30 \mathrm{~m}$ inward from the edges to avoid the "contamination" caused by pixels from outside the experimental plot. The NDVI and SAVI vegetation indexes were used. Vegetation indexes are spectral transformations of at least two spectral bands, chosen specifically to enhance the contribution of vegetation properties to surface reflectance (Falk et al., 2004). It has been widely reported that phenological trajectory or seasonal and interannual change in vegetation growth and activity (Jensen, 2007). NDVI and SAVI were calculated with the following equations based on the Landsat ETM+ data and the "Interpreter spectral enhancement" module of the software Erdas 9.2.

$$
\mathrm{NDVI}=\frac{(\mathrm{B} 4 \mathrm{~B} 3)}{(\mathrm{B} 4+\mathrm{B} 3)}
$$

$$
\mathrm{SAVI}=\frac{(\mathrm{B} 4 \mathrm{~B} 3)}{(\mathrm{B} 4+\mathrm{B} 3+\mathrm{L})}(1+\mathrm{L}) \text { For }=0.5
$$

where B4 and B3 denote the reflectance value of the fourth (the near-infrared band) and third bands (the red band) of the pre-processed images. $\mathrm{L}$ is adjustment factor (value $=0.5$ ). Data were subjected to analysis of variance (ANOVA). Mean separation was done by Duncan's multiple range test at 5\% level of significance. Statistical procedures were performed using software SAS. 


\section{Results and discussion}

Phenological growth stages at the three sites are presented in Table 3.

High interannual and site variation for phenology and GDD values was observed (Table 4).

Time of occurrence of the different phenological stages was dependent on the year and the site. Large differences in the time of occurrence of the different phenological stages and GDD values $\left(6^{\circ} \mathrm{C}\right.$ and $10^{\circ} \mathrm{C}$ bases) were observed within sites and years for the same phenological events. For example, the dates of the beginning of flowering ( $\mathrm{BBCH}$ 61) varied annually by 17 days for the same sites $(\mathrm{C} 2, \mathrm{C} 3)$, and GDD showed high coefficient of variation
(CV) (Table 3). Differences in ripening times ranged up to 28 days between the three sites for the same year (2010) and up to 15 days between years $(\mathrm{C} 1)$. Variation in the time of the different phenological stages among the sites was not always related to differences in temperature and GDD. Different potential mechanisms may account for these results. Growing degree days (GDD) considers only the sum of daily mean temperature (Tmean) above a fixed threshold value (Piao et al., 2015). Current phenological models that use daily mean temperature ignore potentially different responses of plants to daytime and nighttime warming (Peng et al., 2013; Fu et al., 2014). According to Piao et al. (2015), daytime rather than nighttime warming in spring

Table 3. Phenological growth stages (BBCH scale) at the studied sites ( $\mathrm{C} 1, \mathrm{C} 2$, and $\mathrm{C} 3)$.

\begin{tabular}{|c|c|c|c|c|c|c|c|c|c|c|}
\hline \multirow[t]{2}{*}{$\mathrm{BBCH}$} & \multirow[t]{2}{*}{ Description } & \multirow[t]{2}{*}{ Site } & Date & $\begin{array}{r}\text { GDD } \\
10^{\circ} \mathrm{C} \\
\end{array}$ & $\begin{array}{c}\text { GDD } \\
6^{\circ} \mathrm{C} \\
\end{array}$ & Days acc. & \multirow[t]{2}{*}{ Date } & $\begin{array}{l}\text { GDD } \\
10^{\circ} \mathrm{C} \\
\end{array}$ & $\begin{array}{l}\text { GDD } \\
6^{\circ} \mathrm{C} \\
\end{array}$ & \multirow[t]{2}{*}{ Days acc. } \\
\hline & & & \multicolumn{4}{|c|}{2010} & & \multicolumn{2}{|c|}{2011} & \\
\hline \multirow[t]{6}{*}{03} & End of leaf bud swelling & Romeral (C1) & 26.08 & 13.0 & 97.2 & 57 & 30.07 & 1.2 & 27.8 & 30 \\
\hline & & Rauco (C2) & 20.08 & 21.1 & 110.7 & 51 & 20.08 & 13.9 & 79.0 & 51 \\
\hline & & Sagrada F (C3) & 11.08 & 35.0 & 49.7 & 42 & 20.08 & 17.4 & 99.3 & 51 \\
\hline & & Sagrada F (C3) & 11.08 & 35.0 & 49.7 & 42 & 20.08 & 17.4 & 99.3 & 51 \\
\hline & Mean & & & 23.0 & 85.86 & 50 & & 10.8 & 68.8 & 44 \\
\hline & $\mathrm{CV}$ & & & 83.7 & 64.62 & 26.2 & & 136.3 & 92.9 & 47.7 \\
\hline \multirow[t]{5}{*}{61} & Beginning of flowering & Romeral (C1) & 13.09 & 24.0 & 165.6 & 75 & 10.09 & 70.9 & 208.0 & 72 \\
\hline & & Rauco (C2) & 13.09 & 53.4 & 231.7 & 75 & 30.09 & 62.2 & 256.7 & 92 \\
\hline & & Sagrada F (C3) & 13.09 & 45.8 & 212.1 & 75 & 30.09 & 90.6 & 316.0 & 92 \\
\hline & Mean & & & 41.06 & 203.1 & 75 & & 74.6 & 260.2 & 85.3 \\
\hline & $\mathrm{CV}$ & & & 290 & 130.5 & 0 & & 152.4 & 162.3 & 105.7 \\
\hline \multirow[t]{5}{*}{75} & $50 \%$ of final fruit size & Romeral (C1) & 8.10 & 56.8 & 292.3 & 100 & 15.10 & 142.6 & 416.0 & 107 \\
\hline & & Rauco (C2) & 8.10 & 108.1 & 385.8 & 100 & 15.10 & 87.7 & 340.1 & 107 \\
\hline & & Sagrada F (C3) & 8.10 & 101.8 & 367.3 & 100 & 15.10 & 129.2 & 414.2 & 107 \\
\hline & Mean & & & 88.9 & 384.5 & 100 & & 119.8 & 390.1 & 107 \\
\hline & $\mathrm{CV}$ & & & 272.5 & 123.0 & 0 & & 206.9 & 96.1 & 0 \\
\hline \multirow[t]{5}{*}{81} & Fruit coloring & Romeral (C1) & 20.11 & 274.3 & 292.3 & 143 & 11.11 & 269.6 & 651.0 & 134 \\
\hline & & Rauco (C2) & 20.11 & 318 & 766.1 & 143 & 11.11 & 210.2 & 570.6 & 134 \\
\hline & & Sagrada F (C3) & 05.11 & 250.0 & 626.1 & 128 & 11.11 & 290.7 & 683.7 & 134 \\
\hline & Mean & & & 280.8 & 561.5 & 138 & & 256.8 & 635.1 & 134 \\
\hline & $\mathrm{CV}$ & & & 110.5 & 390.2 & 56.5 & & 146.3 & 82.5 & 0 \\
\hline \multirow[t]{5}{*}{87} & Fruit ripe for picking & Romeral (C1) & 18.12 & 459.5 & 976.5 & 171 & 03.12 & 418.1 & 887.5 & 156 \\
\hline & & Rauco (C2) & 10.12 & 450.6 & 978.6 & 163 & 03.12 & 358.2 & 806.6 & 156 \\
\hline & & Sagrada F (C3) & 20.11 & 352.7 & 788.8 & 143 & 03.12 & 459.7 & 940.6 & 156 \\
\hline & Mean & & & 420.9 & 914.6 & 159.0 & & 412.0 & 878.2 & 156 \\
\hline & $\mathrm{CV}$ & & & 131.3 & 111.1 & 84.6 & & 115.5 & 71.7 & 0 \\
\hline
\end{tabular}

Note. Growing degree-days (GDD) accumulated starting from the first of July (period 2010-2011). 
Table 4. Comparison between phenological stages $(\mathrm{BBCH})$ and vegetative indexes (NDVI, SAVI) for cherry trees at the three locations of the study $(\mathrm{C} 1, \mathrm{C} 2, \mathrm{C} 3)$.

\begin{tabular}{|c|c|c|c|c|c|c|c|c|c|}
\hline \multirow{2}{*}{ Date } & \multicolumn{3}{|c|}{ Romeral (C1) } & \multicolumn{3}{|c|}{ Rauco (C2) } & \multicolumn{3}{|c|}{ Sagrada Familia (C3) } \\
\hline & $\mathrm{BBCH}$ & NDVI & SAVI & $\mathrm{BBCH}$ & NDVI & SAVI & $\mathrm{BBCH}$ & NDVI & SAVI \\
\hline 22.1 .10 & $\begin{array}{l}\text { 91. Shoot growth } \\
\text { completed; foliage } \\
\text { still fully green }\end{array}$ & $0.40 \mathrm{bc}$ & $0.44 \mathrm{~cd}$ & $\begin{array}{l}\text { 91. Shoot growth } \\
\text { completed; foliage } \\
\text { still fully green }\end{array}$ & $0.42 \mathrm{c}$ & $0.48 \mathrm{c}$ & $\begin{array}{l}\text { 91. Shoot growth } \\
\text { completed; } \\
\text { foliage still } \\
\text { fully green }\end{array}$ & $0.42 \mathrm{c}$ & $0.46 \mathrm{~b}$ \\
\hline 12.4 .10 & $\begin{array}{l}\text { 93. Beginning of } \\
\text { leaf fall }\end{array}$ & $0.38 \mathrm{~cd}$ & $0.42 \mathrm{~d}$ & $\begin{array}{l}\text { 93. Beginning of } \\
\text { leaf fall. }\end{array}$ & $0.35 \mathrm{e}$ & $0.44 \mathrm{e}$ & $\begin{array}{l}\text { 93. Beginning of } \\
\text { leaf fall. }\end{array}$ & $0.35 \mathrm{~d}$ & $0.41 \mathrm{c}$ \\
\hline 6.11 .10 & $\begin{array}{l}\text { 90. Coloring } \\
\text { advanced }\end{array}$ & $0.35 \mathrm{de}$ & $0.53 \mathrm{a}$ & $\begin{array}{l}\text { 79. Fruit about } 90 \% \text { of } \\
\text { final size. }\end{array}$ & $0.45 \mathrm{~b}$ & $0.51 \mathrm{~b}$ & $\begin{array}{l}\text { 79. Fruit about } 90 \% \\
\text { of final size. }\end{array}$ & $0.48 \mathrm{a}$ & $0.54 \mathrm{a}$ \\
\hline 9.1 .11 & $\begin{array}{l}\text { 91. Shoot growth } \\
\text { completed; foliage } \\
\text { still fully green }\end{array}$ & $0.29 \mathrm{f}$ & $0.50 \mathrm{~b}$ & $\begin{array}{l}\text { 91. Shoot growth } \\
\text { completed; foliage } \\
\text { still fully green }\end{array}$ & $0.47 \mathrm{a}$ & $0.54 \mathrm{a}$ & $\begin{array}{l}\text { 91. Shoot growth } \\
\text { completed; } \\
\text { foliage still } \\
\text { fully green }\end{array}$ & $0.46 \mathrm{~b}$ & $0.55 \mathrm{a}$ \\
\hline 30.3 .11 & $\begin{array}{l}\text { 92. Leaves begin } \\
\text { to fade colour. }\end{array}$ & $0.32 \mathrm{ef}$ & $0.36 \mathrm{e}$ & $\begin{array}{l}\text { 92. Leaves begin } \\
\text { to fade }\end{array}$ & $0.37 \mathrm{~d}$ & $0.38 \mathrm{~g}$ & $\begin{array}{l}\text { 92. Leaves begin } \\
\text { to fade }\end{array}$ & $0.35 \mathrm{~d}$ & $0.36 \mathrm{~d}$ \\
\hline 6.9 .11 & $\begin{array}{l}\text { 51. Inflorescence } \\
\text { buds swelling }\end{array}$ & $0.37 \mathrm{~cd}$ & $0.31 \mathrm{f}$ & $\begin{array}{l}\text { 51. Infloresc buds } \\
\text { swelling }\end{array}$ & $0.23 \mathrm{f}$ & $0.35 \mathrm{~h}$ & $\begin{array}{l}\text { 51. Infloresc. buds } \\
\text { swelling }\end{array}$ & $0.23 \mathrm{e}$ & $0.36 \mathrm{~d}$ \\
\hline 25.11 .11 & $\begin{array}{l}\text { 85. Advanced } \\
\text { fruit coloring }\end{array}$ & $0.43 \mathrm{ab}$ & $0.48 \mathrm{~b}$ & $\begin{array}{l}\text { 85. Advance fruit } \\
\text { coloring }\end{array}$ & $0.48 \mathrm{a}$ & $0.42 \mathrm{f}$ & $\begin{array}{l}\text { 85. Advanced fruit } \\
\text { coloring }\end{array}$ & $0.44 \mathrm{bc}$ & $0.44 \mathrm{bc}$ \\
\hline 12.12 .11 & $\begin{array}{l}\text { 89. Fruit ripe for } \\
\text { harvesting }\end{array}$ & $0.45 \mathrm{a}$ & $0.45 \mathrm{c}$ & $\begin{array}{l}\text { 89. Fruit ripe for } \\
\text { harvesting }\end{array}$ & $0.45 \mathrm{~b}$ & $0.47 \mathrm{~d}$ & $\begin{array}{l}\text { 89. Fruit ripe for } \\
\text { harvesting }\end{array}$ & $0.44 b$ & $0.47 \mathrm{~b}$ \\
\hline
\end{tabular}

Means followed by the same letter do not differ at $\mathrm{P} \leq 0.05$, according to Tukey's multiple range t-test.

fulfills more efficiently the GDD requirement that triggers leaf onset. Another mechanism is the possible role of photoperiod in co-regulating spring phenology (Körner and Basler, 2010). According to our observations, the number of days accumulated starting from the first of July tended to be a less variable indicator than GDD for the occurrence of different phenological stages (showed lower coefficient of variation). Time of phenological growth stages varied in some extent during 2010-2011 but on average C3 achieved the stage of fruit ripeness earlier whereas $\mathrm{C} 1$ was the latest. The capacity to discriminate phenological events at each of the three sites on the basis of the two studied vegetation indexes generally was very low (Table 4). Cherry trees showed quite similar spectral behavior (low spectral variability), especially during some particular phenological stages, and in some cases also large differences of NDVI values within sites were observed for the same dates and phenological stages (BBCH stages 90 and 91). On the basis of the obtained results is not possible to discriminate between successive phenological states in which the proportion of foliage is only slightly different. It seems that from an optical remote sensing perspective, satellite images and the derived vegetative indexes could discriminate only gross changes associated with an increase and then decrease in canopy greenness (foliage still fully green compared to leaf senescence). This period of early leaf growth and chlorophyll accumulation, as well as leaf senescence and abscission often extended over several weeks, including different phenological stages that could not be discriminated. While Landsat has been utilized for many vegetation applications, assessments of phenology are limited (White et al., 2014). Landsat 7 (ETM+) data at $30 \mathrm{~m}$ resolution has been mainly utilized to classify the phenological behavior of agricultural crops and to estimate productivity in forest stands (Goetz and Prince, 1996). A strong relationship between field-measured phenological stages and 
satellite-derived vegetation greenness has been found mostly for dense forest plots (Melaas and Zhu, 2013). A general tendency towards higher values of both indices can be seen, as according to the phenological state, greater leaf cover is expected. For example, generally higher values were obtained at harvest time (maximum foliage development is expected) than before leaf fall, when the chlorophyll begins to degrade in the leaves and we may expect a different spectral response. The values obtained for SAVI were mostly greater than for NDVI for the same sites and dates. This reflects in part the action of this index in minimizing the effect of bare soil near vegetation (Allen et al., 2010). The capacity for studying phenological stages of cherry trees has been probably limited by coarse spatial and temporal resolution and the lack of a direct link to field observations. A tendency may be appreciated towards higher NDVI and SAVI values as, depending on the phenological stage, a higher leaf area index and leaf chlorophyll content are expected. For example, significantly higher values of both indexes were observed during $\mathrm{BBCH}$ stage 89 (Fruit ripe for harvesting) compared to BBCH stage 92 (Leaves begin to fade color) when lower spectral reflectance is expected because of decreased chlorophyll content (Table 4). SAVI values tended to be higher than NDVI for the same dates and sites. This partially reflects the capacity of this index to minimize soil brightness influences and its effects on red and near-infrared (NIR) wavelengths (Huete, 1988).

\section{Conclusions}

Phenological transition stages in cherry trees estimated from Landsat 7 (ETM+) data did not agree with in situ measurements of phenology collected at the different sites. Specific phenological transition dates could not be estimated precisely using Landsat data and the derived vegetative indexes (NDVI, SAVI). Landsat 7 (ETM+) derived vegetation indices could discriminate only gross changes associated with an increase and then decrease of canopy greenness in cherry trees, but could not discriminate between successive phenological states in which the proportion of foliage is only slightly different. This may be useful for identifying and characterizing large areas of cherry cultivation, but it is not sufficient to discriminate minor changes in phenology. The number of days accumulated starting from the first of July tended to be a less variable indicator than GDD for predicting the time of different phenological stages in cherry trees. Variation in the timing of different phenological stages among the sites was not always related to differences in temperature and GDD.

\section{Acknowledgments}

The research leading to these results received funding from the Chilean funding agencies INNOVA-CORFO under grant no 09CN14-5784 and CONICYT res. ex. N 1399.

\section{Literature Cited}

Allen, R.G.; Tasumi, M.; Morse, A.; Trezza, R.; Wright, J.; Bastiaanssen, W.; Kramber, W.; Lorite, I.; Robison, C.W. 2007. Satellite-based energy balance for mapping evapotranspiration with internalized calibration (METRIC) applications. Journal of Irrigation and Drainage Engineering 133 (4): 395-406.

Barbosa, H.A.; Heute, A.R.; Baethgen, W.E.

2006. A 20-year study of NDVI variability over the northeast region of Brazil. Journal of arid environments 67 (2): 288-307.

Carrasco-Benavides, M.; Ortega-Farías, S.; Lagos, L.; Kleissl,

J.; Morales-Salinas, L.; Kilic, A.

2014. Parameterization of the satellite-based model (METRIC) for the estimation of instantaneous surface energy balance components over a drip-irrigated vineyard. Remote Sensing 6 (11): 11342-11371.

Casanova M., Luzio W., Maldonado R.

2007. Correlation between world reference base and soil taxonomy for the soils from the $7^{\text {th }}$ Region del Maule from Chile. Revista Chilena de la Ciencia del Suelo y Nutrición Vegetal 7 (2): 14-21.

Chmielewski, F.M.

2003. Phenology and agriculture. In: Schwartz MD, editor. Phenology an integrative environmental science. Dodrecht, The Netherlands, pp. 505-522.

Chuvieco, E.

2002. Teledetección ambiental. $3^{\text {rd }}$ ed. Barcelona, Spain: Ariel Ciencias. 608 p.

Falk, M.; Meyers, T.; Black, A.; Barr, A.; Yamamoto, S.; Verma, S.; Baldocchi, D.

2004. Seasonal course of normalized difference vegetation index 'NDVI' derived from tower data. Proceedings 26th conference on agricultural and forest meteorology. Vancouver, Canada.

Fu, Y. H.; Piao, S.; Zhao, H.; Jeong, S.; Wang, X.; Vitasse, Y.; Ciais, P.; Janssens, I.A.

2014. Unexpected role of winter precipitation in determining heat requirement for spring vegetation green-up at northern 
middle and high latitudes. Global Change Biology 20 (12): 3743-3755.

Goetz, S.J.; Prince, S.D.

1996. Remote sensing of net primary production in boreal forest stands. Agricultural and Forest Meteorology 78 (3-4): 149-179.

Huete, A.R.

1988. A soil-adjusted vegetation index (SAVI). Remote Sensing of Environment 25 (3): 295-309.

Jensen, J.

2007. Remote sensing of the environment. An earth resource perspective. 2nd ed. USA: Prentice Hall. 608 p.

Körner, C.; Basler, D.

2010. Phenology under global warming. Science 327 (5972): 1461-1462.

Lauri, P.

2005. Developments in high density cherries in France: integration of tree architecture and manipulation. Acta Horticulturae 667: 285-291.

Meier, U.; Graf, M.; Hess, W.; Kennel, R.; Klose, D.; Mappes, D.; Seipp, R.; Stauss, J.; Streif, T.; Van den Boom; T. 1994. Phänologische Entwicklungsstadien des Kernobstes (Malus domestica Borkh. und Pyrus communis L.), des Steinobstes (Prunus-Arten), der Johannisbeere (Ribes-Arten) und der Erdbeere (Fragaria x ananassa Duch.). Nachrichtenblatt des Deutschen Pflanzenschutzdienstes 46: 141-153.

Melaas E.K., Friedl M.A., Zhu Z.

2013. Detecting interannual variation in deciduous broadleaf forest phenology using Landsat TM/ETM+ data. Remote Sensing of Environment 132: 176-185.
Peng, S.; Piao, S.; Ciais, P.; Myneni, R.; Chen, A.; Chevallier, F.; Dolman, A.; Janssens, I.; Peñuelas, J.; Zhang, G.; Vicca, S.; Wan, S.; Wang, S.; Zeng, H.

2013. Asymmetric effects of daytime and night-time warming on Northern Hemisphere vegetation. Nature 501: 88-92.

Piao, S.; Tan, J.; Chen, A.; Fu, Y.H.; Ciais, P.; Liu, Q.; Janssens, I.A.; Vicca, S.; Zeng, Z.; Jeong, S.; Li, Y.; Myneni, R.B.; Peng, S.; Shen, M.; Peñuelas, J.

2015. Leaf onset in the northern hemisphere triggered by daytime temperature. Nature Communications 6: 6911.

Rastetter, E.B.; King, A.W.; Cosby, B.J.; Hornberger, G.M.;

O’Neill, R.V.; Hobbie, E.

1992. Aggregating fine-scale ecological knowledge to model coarser-scale attributes of ecosystems. Ecological Applications 2 (1): 55-70.

Tasumi, M.; Allen, R.G.; Trezza, R.

2008. At-surface reflectance and albedo from satellite for operational calculation of land surface energy balance. Journal of Hydrologic Engineering 13 (2): 51-63.

White, K.; Schaberg, B.

2014. Remote sensing of spring phenology in northeastern forests: a comparison of methods, field metrics and sources of uncertainty. Remote Sensing of Environment 148: 97-107.

Zavalloni, C.; Andresen, J.A.; Flore, J.A.

2006. Phenological models of flower bud stages and fruit growth of 'Montmorency' sour cherry based on growing degree-day accumulation. Journal of the American Society for Horticultural Science 131 (5): 601-607. 
